Resectron

\title{
RNase L contributes to experimentally induced type 1 diabetes onset in mice
}

\author{
Chun Zeng', Xin Yi ${ }^{1}$, Danny Zipris ${ }^{4}$, Hongli Liu ${ }^{5}$, Lin Zhang ${ }^{1}$, Qiaoyun Zheng ${ }^{1}$, \\ Krishnamurthy Malathi ${ }^{6}$, Ge Jin $^{7}$ and Aimin Zhou ${ }^{1,2,3}$ \\ ${ }^{1}$ Clinical Chemistry Program, Department of Chemistry, Cleveland State University, SI 424, Cleveland, \\ Ohio 44115, USA \\ ${ }^{2}$ Center for Gene Regulation in Health and Diseases, Cleveland State University, Cleveland, Ohio 44115, USA \\ ${ }^{3}$ Department of Cancer Biology, Lerner Research Institute, Cleveland Clinic, Cleveland, Ohio 44195, USA \\ ${ }^{4}$ Barbara Davis Center of Childhood Diabetes, University of Colorado Health Science Center, Denver, Colorado \\ 80045 , USA \\ ${ }^{5}$ Central Laboratory, the Eighth Hospital of Xi'an, 2 East Zhangba Road, Xi'an 710061, China \\ ${ }^{6}$ Department of Biological Sciences, University of Toledo, Toledo, Ohio 43606, USA \\ ${ }^{7}$ Department of Biological Sciences, Case Western Reserve University School of Dental Medicine, Cleveland, \\ Ohio 44106, USA
}

Correspondence should be addressed to A Zhou

Email

a.zhou@csuohio.edu

\begin{abstract}
The cause of type 1 diabetes continues to be a focus of investigation. Studies have revealed that interferon $\alpha$ (IFN $\alpha)$ in pancreatic islets after viral infection or treatment with double-stranded RNA (dsRNA), a mimic of viral infection, is associated with the onset of type 1 diabetes. However, how IFN $\alpha$ contributes to the onset of type 1 diabetes is obscure. In this study, we found that 2-5A-dependent RNase $L$ (RNase L), an IFN $\alpha$-inducible enzyme that functions in the antiviral and antiproliferative activities of IFN, played an important role in dsRNA-induced onset of type 1 diabetes. Using RNase L-deficient, rat insulin promoter-B7.1 transgenic mice, which are more vulnerable to harmful environmental factors such as viral infection, we demonstrated that deficiency of RNase $L$ in mice resulted in a significant delay of diabetes onset induced by polyinosinic:polycytidylic acid (poly I:C), a type of synthetic dsRNA, and streptozotocin, a drug which can artificially induce type 1-like diabetes in experimental animals. Immunohistochemical staining results indicated that the population of infiltrated $\mathrm{CD} 8^{+} \mathrm{T}$ cells was remarkably reduced in the islets of RNase L-deficient mice, indicating that RNase L may contribute to type 1 diabetes onset through regulating immune responses. Furthermore, RNase $L$ was responsible for the expression of certain proinflammatory genes in the pancreas under induced conditions. Our findings provide new insights into the molecular mechanism underlying $\beta$-cell destruction and may indicate novel therapeutic strategies for treatment and prevention of the disease based on the selective regulation and inhibition of RNase $\mathrm{L}$.
\end{abstract}
Key Words
- RNase L
- type 1 diabetes
- interferon
- poly I:C
- immune cells

\section{Introduction}

The etiology of diabetes continues to be a focus of investigation. Both genetic and environmental factors such as toxins, viruses, and diets are believed to play an important role in its pathogenesis (Mathis et al. 2001). A reduction in insulin-producing pancreatic $\beta$-cells has been considered to be one of the key factors in the 
development of diabetes, particularly type 1 diabetes (Yoon $\&$ Jun 2001, Mandrup-Poulsen 2003). In type 1 diabetes, autoimmune destruction of the pancreatic $\beta$-cells results in an absolute loss of insulin production. Investigation of the molecular mechanisms underlying $\beta$-cell destruction has revealed that microbial infection recruits immune effectors mediating $\beta$-cell apoptosis, which in turn triggers autoimmune responses (Anderson \& Bluestone 2005). NOD mice are an ideal model of spontaneous type 1 diabetes, a T-cellmediated autoimmune disease. Results from histological studies have indicated that infiltration of immune cells, including macrophages and lymphocytes, around the islets in NOD mice starts at 3-4 weeks of age, causing insulitis (Solomon \& Sarvetnick 2004, Anderson \& Bluestone 2005). It has been well demonstrated that $\mathrm{CD} 4^{+}$and $\mathrm{CD} 8^{+} \mathrm{T}$ cells play an important role in the onset of type 1 diabetes. Results from clinical and animal studies have demonstrated that $\mathrm{CD} 8{ }^{+} \mathrm{T}$ cells take a central stage in the destruction of pancreatic $\beta$-cells and contribute to sustaining islet inflammation, leading to the onset of type 1 diabetes (Solomon \& Sarvetnick 2004, Anderson \& Bluestone 2005, Coppieters \& von Herrath 2011, Coppieters et al. 2012).

The expression of proinflammatory genes has been implicated in the pathogenesis of type 1 diabetes (Bergholdt et al. 2004). In NOD mice, increased expression of IFN $\gamma$, TNF $\alpha$, and IL1 $\beta$ is associated with $\beta$-celldestructive insulitis (Solomon \& Sarvetnick 2004, Anderson \& Bluestone 2005). In recent years, the role of IFN $\alpha$ in autoimmune diseases including type 1 diabetes has been well established (Selmi et al. 2006). Increased levels of IFN $\alpha$ in the sera of type 1 diabetic patients have been documented (Chehadeh et al. 2000). Transgenic mice expressing IFN $\alpha$ (IFNA) in the $\beta$-cells develop hypoinsulinemic diabetes associated with a mixed inflammation centered on the islet, which can be prevented with a neutralizing antibody to IFN $\alpha$ (Stewart et al. 1993). It has been reported that the onset of type 1 diabetes in both BB rats and streptozotocin (STZ)-treated mice is IFN $\alpha$ dependent (Huang et al. 1994). In addition, IFN $\alpha$ mediates induction of type 1 diabetes by poly I:C in mice expressing the B7.1 costimulatory molecule driven by the rat insulin promoter (RIP) on $\beta$-cells in islets (Devendra et al. 2005). Most recently, a study has revealed that blockade of IFN $\alpha$ signaling by anti-IFNAR1 in 2- to 3-week-old NOD mice remarkably delays the onset and decreases the incidence of diabetes, indicating the involvement of IFN-stimulated genes in the pathogenesis of type 1 diabetes (Li et al. 2008).

RNase $\mathrm{L}$ is an IFN-inducible enzyme and plays an important role in the 2-5A system of IFN action against viral infection and cellular proliferation (Silverman 1996).
The 2-5A system consists of two enzymes: $2-5 \mathrm{~A}$ synthetase and RNase L. IFNs induce a family of 2-5A synthetase genes. The 2-5A synthetases require double-stranded RNA (dsRNA) for their activities. dsRNA is frequently produced during viral infection. After activation by dsRNA, 2-5A synthetases convert ATP molecules to pyrophosphate (ppi) and a series of unique, $5^{\prime}$-phosphorylated, $2^{\prime}-5^{\prime}$ linked oligoadenylates known as $2-5 \mathrm{~A}$ with the general formula $\operatorname{ppp}\left(\mathrm{A}^{\prime}{ }^{\prime} 5^{\prime}\right) \mathrm{nA}$ $(n \geq 2)$. 2-5A binds RNase L with a high affinity, converting it from its inactive, monomeric state to a potent dimeric endoribonuclease, resulting in degradation of singlestranded viral and cellular RNAs (Zhou et al. 1993). It has been demonstrated that $2-5 \mathrm{~A}$ accumulates and RNase $\mathrm{L}$ is activated in infected cells. Cells overexpressing RNase $\mathrm{L}$ overcome viral infection (Zhou, et al. 1998). In contrast, overexpression of a dominant negative mutant of RNase $\mathrm{L}$ results in increased susceptibility to certain viruses (Hassel et al. 1993). Results from in vivo studies indicated that mice containing targeted disruption of RNase L gene succumb to encephalomyocarditis (EMCV) infection more rapidly than infected WT mice (Zhou et al. 1997). Interestingly, 2-5A synthetase is persistently activated in patients with type 1 diabetes, indicating its involvement in this disease (Bonnevie-Nielsen et al. 2000). RNase L-null mice show enlarged thymus glands and increased $\mathrm{T}$ cell numbers at an early age, indicating that RNase L may be involved in $\mathrm{T}$ cell development, which probably results from reduced cell apoptosis. Furthermore, it has been demonstrated that overexpression of RNase $\mathrm{L}$ in the cells enhances cell apoptosis, whereas dominant negative RNase L suppresses cell apoptosis (Zhou et al. 1997). These observations indicate that RNase L plays an important role in the immune system. Indeed, studies have revealed that skin allograft rejection is suppressed in mice lacking RNase $\mathrm{L}$, indicating the involvement of RNase $\mathrm{L}$ in $\mathrm{T}$ cell immunity, particularly $\mathrm{CD} 4^{+} \mathrm{T}$ cell-mediated immunity (Silverman et al. 2002). In addition, alphavirus-based DNA vaccination against a non-mutated tumor-associated selfantigen (tyrosinase-related protein-1, TRP-1) is severely impaired in RNase L-null mice, indicating that RNase L plays an important role in the host's immune response against cancer (Leitner et al. 2003).

In this study, we present evidence indicating that RNase $\mathrm{L}$ may be involved in the pathogenesis of type 1 diabetes. RNase L-deficient RIP-B7.1 mice displayed significantly delayed onset of diabetes induced by STZ and poly I:C. Immunohistostaining revealed that the population of infiltrated $\mathrm{CD} 8{ }^{+} \mathrm{T}$ cells was remarkably reduced in the islets of RNase L-deficient mice, implicating RNase $\mathrm{L}$ in the onset of type 1 diabetes through mediating

Published by Bioscientifica Ltd.

Downloaded from Bioscientifica.com at $04 / 26 / 2023$ 08:23: $02 \mathrm{AM}$ via free access 
the infiltration of immune cells. Furthermore, RNase L regulated the expression of certain proinflammatory genes in the pancreas under these conditions. Our results are indicative of a novel role of RNase $\mathrm{L}$ in the development of type 1 diabetes.

\section{Reagents and methods}

\section{Tissue culture and animal treatment}

NIH 3T3 cells, NIT-1 (ATCC, Manassas, VA, USA), and mouse embryonic fibroblasts (MEFs) were grown in DMEM (Cleveland Clinic, Cleveland, OH, USA) supplemented with $10 \%$ fetal bovine serum (PAA Laboratories, Dartmouth, MA, USA) and antibiotics in a humidified atmosphere of 5\% $\mathrm{CO}_{2}$ at $37^{\circ} \mathrm{C}$. BMMs were generated from the bone marrow cells of RNase L-deficient and WT C57BL/6 mice using a modified method (Yi et al. 2013). For RNase L induction in the pancreas of mice, each group $(n=2)$ of $\mathrm{C} 57 \mathrm{BJ} / 6$ mice were treated with or without poly I:C at a concentration of $5 \mu \mathrm{g} / \mathrm{g}$ body weight every other days for 1 week (three times). The pancreases were removed and tissue extracts were used for analysis of RNase L. For treatment with a high-fat diet, RNase $\mathrm{L}^{+/+}$and RNase $\mathrm{L}^{-/-}$mice were fed a high-fat diet (21\% milk fat, $1.25 \%$ cholesterol, and $0.5 \%$ sodium cholate) (Harlan Teklad, Madison, WI, USA) for 20 weeks. The body weight was monitored every 2 weeks and the blood from the eye corner was collected for analysis of glucose, cholesterol, triglyceride, and insulin. This study was carried out in strict accordance with the recommendations in the Guide for the Care and Use of Laboratory Animals of the National Institutes of Health. The protocol was approved by the Committee on the Ethics of Animal Experiments of Cleveland State University (Permit Number: 21111-ZHO-AS). All efforts were made to reduce suffering. Mice were anaesthetized under $\mathrm{CO}_{2}$ for $5 \mathrm{~min}$ and then their necks were dislocated at the end of the experiments.

\section{Generation of an RNase L-deficient C57BL/6.RIP-B7.1 mouse}

An RNase $\mathrm{L}^{-1-}$ mouse (C57BL/6) (a generous gift from Dr Robert Silverman, Cleveland Clinic) was cross-bred with a C57BL/6.RIP-B7.1 mouse (Barbara Davis Center of Childhood Diabetes, University of Colorado Health Sciences Center, Denver, CO, USA). Genotyping for RNase $\mathrm{L}$ and B7.1 was performed by PCR under the following conditions: denaturation at $96^{\circ} \mathrm{C}$ for $4 \mathrm{~min}$, for each cycle, denaturation at $96^{\circ} \mathrm{C}$ for $45 \mathrm{~s}$, annealing at $55^{\circ} \mathrm{C}$ for $45 \mathrm{~s}$, and extension at $72{ }^{\circ} \mathrm{C}$ for $1.5 \mathrm{~min}$, for
32 cycles, then an additional cycle at $72{ }^{\circ} \mathrm{C}$ for $5 \mathrm{~min}$. The primers used were as follows: RNase L, $5^{\prime}$-GCA TTG AGG ACC ATG GAG AC-3' and 5'-GGA GGA GAA GCT TTA CAA GGT-3' and, B7.1, 5'-TGA AGC CAT GGG CCA CAC-3' and 5'-GGC TCC TTG TCG GCG TTC TA-3'.

\section{Diabetes induction}

Six-week-old RNase L-deficient and WT C57BL/6 RIP-B7.1 mice received i.p. injections of with poly I:C (Sigma) daily at a concentration of $5 \mu \mathrm{g} / \mathrm{g}$ body weight for 7 days, and then immunized (i.p.) with $25 \mu \mathrm{g} /$ mouse insulin (Eli Lilly, Indianapolis, IN, USA) on day 14 after poly I:C treatment. Blood glucose was measured weekly using a Glucose Oxidase Reagent Set (Pointe Scientific, Canton, MI, USA). Briefly, $10 \mu \mathrm{l}$ of plasma was mixed with $1 \mathrm{ml}$ of the working reagent provided by the manufacturer and incubated at $37^{\circ} \mathrm{C}$ for exactly $5 \mathrm{~min}$. After incubation, the absorbance at $500 \mathrm{~nm}$ was read and recorded. Mice were considered diabetic after two consecutive blood glucose values of at least $250 \mathrm{mg} / \mathrm{dl}$.

\section{Immunohistostaining}

The pancreases obtained from mice were fixed in $10 \%$ formalin, paraffin embedded, sectioned at a thickness of $5 \mu \mathrm{m}$, and subsequently stained with hematoxylin and eosin. Pancreatic sections were microscopically examined for infiltration of immune cells. The tissue sections were incubated with rat polyclonal antibodies against CD4, CD8, F4/80, and CD11b (eBioscience, San Diego, CA, USA) respectively and a MAB to insulin (Abcam, Cambridge, MA, USA), followed by incubation with a biotinylated secondary antibody, and color reaction was obtained by sequential incubation with avidin-peroxidase conjugate and diaminobenzidine-hydrogen peroxide (ICN, Costa Mesa, CA, USA).

\section{Flow cytometry}

Single-cell suspensions from the spleens were stained with conjugated mAbs including FITC-CD4, PE-CD8, FITC-IgD, PE-B220, and PE-cy7-CD25 (BD Pharmingen, San Jose, CA, USA). Cell-associated fluorescence was analyzed with a FACScan instrument and the associated Winlist 5 software.

\section{Western blot analysis}

After treatment, cells were washed twice with ice-cold PBS and collected with a scraper. Western blot analysis

Published by Bioscientifica Ltd 
was performed as described by Mandrup-Poulsen (2003). Pancreatic tissue extracts obtained from mice (two per group) treated with or without poly I:C (Sigma) every other day at a concentration of $5 \mu \mathrm{g} / \mathrm{g}$ body weight for 1 week (three times) were analyzed as described earlier.

\section{ELISA}

The levels of expression of proinflammatory genes in the extracts of the pancreases were measured by ELISA using commercial available kits (eBioscience and R\&D Systems, Minneapolis, MN, USA) according to the manufacturer's instructions. Plates were read at an absorbance of $450 \mathrm{~nm}$ in a 96-well LD 400C microplate reader (Beckman Coulter, Fullerton, CA, USA).

\section{Results}

\section{Minimal impact of RNase L on high-fat-diet-induced obesity}

It has been previously observed that $\mathrm{RNase} \mathrm{L}^{-1-}$ mice gained significantly more body weight than RNase $\mathrm{L}^{+/+}$ mice and displayed hepatic steatosis and lipid droplets within renal tubular epithelial cell cytoplasm during their old age (Fabre et al. 2012). To determine whether RNase L plays any role in the metabolic pathways, we fed RNase $\mathrm{L}^{+/+}$and RNase $\mathrm{L}^{-/-}$mice a high-fat diet for 20 weeks. Surprisingly, the growth rate of both mouse types was almost identical under the same conditions (Fig. 1A). However, the levels of glucose, cholesterol, and triglyceride were $20.4,11.6$, and $2.5 \%$, respectively, higher in the serum from RNase $\mathrm{L}^{-1-}$ mice compared with that from RNase $\mathrm{L}^{+/+}$mice (Fig. 1B, C, and D), although the level of insulin was also $18.7 \%$ higher (E) in the serum from RNase $\mathrm{L}^{-1-}$ mice. These results indicate that RNase $\mathrm{L}$ may not be involved directly in the increase in body weight, but contribute, at least in part, to the metabolic pathways.

\section{IFN $\alpha$ and poly I:C induce the expression of RNase $L$ in the tissues and cells}

RNase L is one of the key enzymes involved in the IFNinduced antiviral and antiproliferative functions. RNase $\mathrm{L}$ is also found to be expressed in almost all types of mammalian cells from mouse to human (Silverman 1996). To examine the expression of RNase L in the pancreas, the tissue extracts of eight different organs from a C57BL/6 mouse (Jackson Laboratory, Bar Harbor, ME, USA) were analyzed by the 2-5A binding assay (Nolan-Sorden et al. 1990). As shown
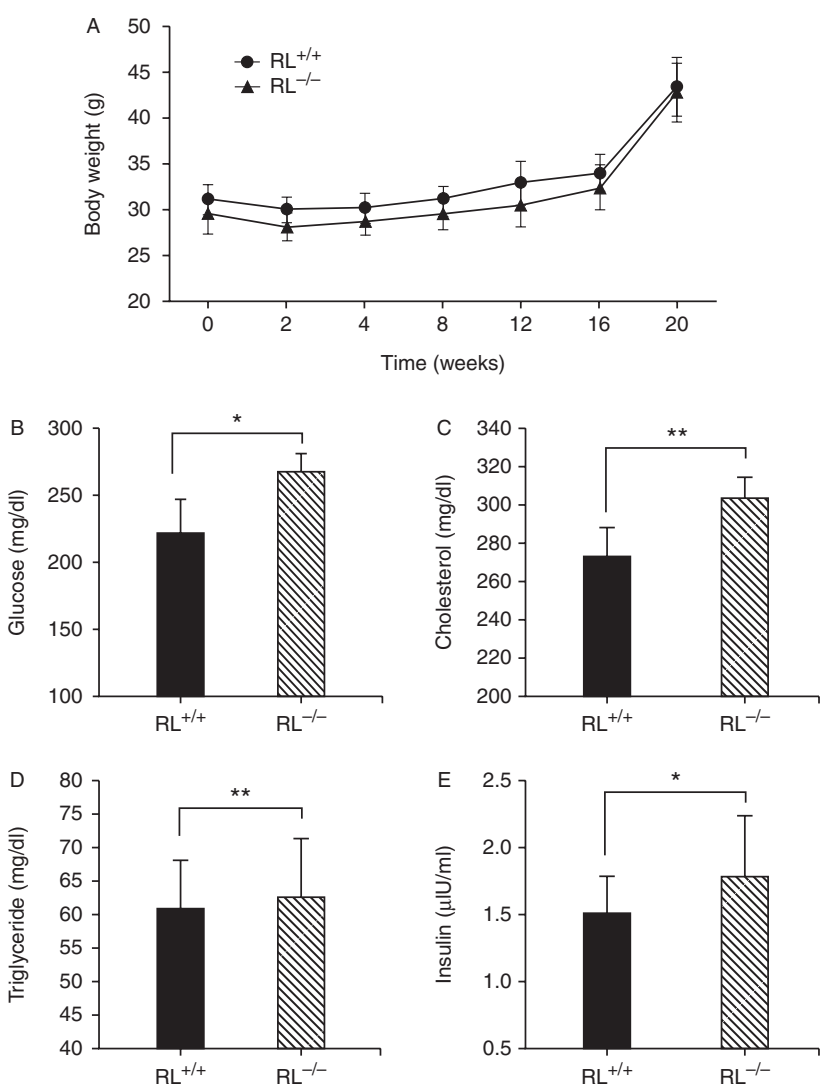

Figure 1

Effect of RNase $\mathrm{L}$ on diet-induced obesity. RNase $\mathrm{L}^{+/+}$and RNase $\mathrm{L}^{-/-}$male mice ( $n=8 /$ group) were fed a high-fat diet (Harlan Teklad) for 20 weeks. The body weight was measured every 2 weeks (A). Glucose (B), cholesterol (C), and triacylglycerol (D) in the plasma were analyzed using commercially available diagnostic kits from Sigma-Aldrich, and insulin (E) was measured using an ELISA kit (Fisher, Hanover, IL, USA). Data are expressed as mean \pm s.D. for eight mice of each strain. The samples were run in triplicate in every assay and two individual experiments were performed, ${ }^{*} P<0.05,{ }^{*} P<0.01$.

in Fig. 2A, RNase L is clearly expressed in the tissues. High levels of the RNase L expression were found in the lung, spleen, and thymus. However, the basal level of RNase L in the pancreas was very low. Similar to our previous observation, RNase L was found to be highly expressed in primary immune cells (Fig. 2B), indicating a possible role of RNase $\mathrm{L}$ in the immune system. To determine whether IFN $\alpha$ is able to induce the expression of RNase $\mathrm{L}$ in the pancreatic cells, NIT cells, a murine $\beta$-cell line, were treated with or without IFN $\alpha$ and the induction of RNase L was examined by western blot analysis. The expression of RNase $\mathrm{L}$ was highly induced in $\beta$-cells (Fig. $2 \mathrm{C}$ ). dsRNA such as poly I:C can be used to mimic viral infection in vitro and in vivo. To examine whether poly I:C is able to upregulate the RNase $\mathrm{L}$ expression in the pancreas, mice were treated with or without poly I:C and the expression of RNase L

Published by Bioscientifica Ltd 
A

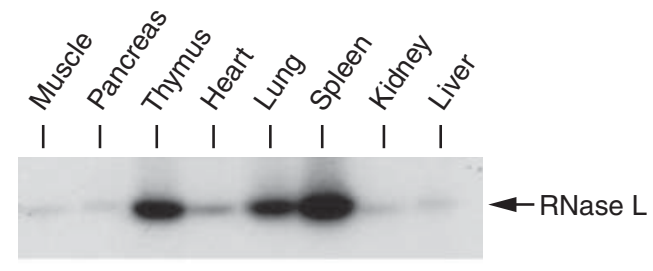

B

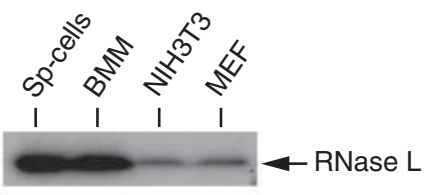

C
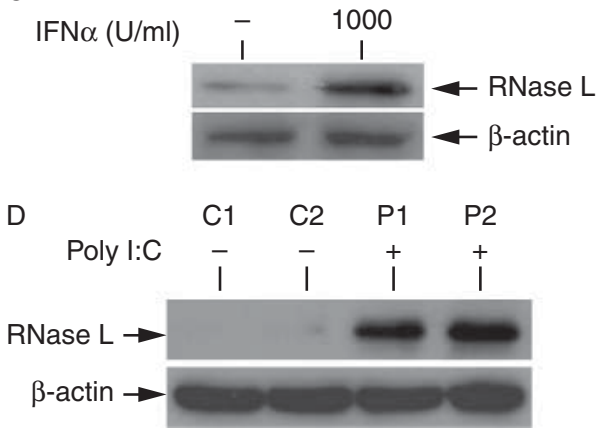

\section{Figure 2}

Tissue distribution and expression of RNase L. The expression of RNase $L$ in the tissue extracts from eight organs (A) and several types of cells (B). $\mathrm{Sp}$-cells, primary splenocytes; BMM, bone marrow-derived macrophages; NIH3T3, mouse fibroblasts; MEFs, mouse embryonic fibroblasts. (C) IFN $\alpha$. induces the expression of RNase L in NIT-1 cells. NIT-1 cells were treated with 1000 units $/ \mathrm{ml}$ of IFN $\alpha$ (R\&D Systems) for $16 \mathrm{~h}$ and the level of RNase $L$ in the cells was determined by western blot analysis. (D) Mice (two per group) were treated with or without poly I:C at a concentration of $5 \mu \mathrm{g} / \mathrm{g}$ body weight every other days for 1 week (three times) and the level of RNase $L$ in the pancreatic tissue extracts was determined by western blot analysis with a polyclonal antibody to mouse RNase L.

in the pancreatic tissue extracts was measured. Poly I:C was a potent inducer of the RNase $\mathrm{L}$ expression in the pancreas (Fig. 2D).

\section{The onset of type 1 diabetes is delayed in RNase-L- deficient mice}

Viral infection is believed to be a potent factor in triggering autoimmune responses in the pancreas, resulting in destruction of $\beta$-cells, leading to absolute deficiency of insulin. Indeed, poly I:C, a type of dsRNA commonly used to mimic viral infection, is able to effectively induce the onset of type 1 diabetes in C57BL/6 mice expressing B7.1 under the control of a RIP on pancreatic $\beta$-cells islets (RIP-B7.1) in an IFN $\alpha$ dependent manner (Devendra et al. 2005). RNase L can be induced by both poly I:C and IFN $\alpha$ in vitro and in vivo and mediates the functions of IFN $\alpha$. To determine the role of RNase $\mathrm{L}$ in the onset of type 1 diabetes induced by poly I:C, RNase $\mathrm{L}^{-1-}$ RIP-B7.1 mice were created by cross-breeding an RNase $\mathrm{L}^{-1-}$ mouse $(\mathrm{C} 57 \mathrm{BL} / 6)$ with a C57BL/6.RIP-B7.1 mouse (RIP-B7.1 mouse). The genotype of these mice was determined by PCR as shown in Fig. 3A. The onset of type 1 diabetes was first induced using STZ, a glucose analog known to induce diabetes in experimental animals. Mice received i.p. injections of $40 \mathrm{mg} / \mathrm{kg}$ STZ for five consecutive days, the blood was collected from the saphenous vein, and the level of glucose was measured as described in the Reagents and methods section. As shown in Fig. 3B, mice with RIP-B7.1 were more sensitive to STZ-induced onset of diabetes and RNase L deficiency markedly delayed the progress of this disease. To determine whether RNase $\mathrm{L}$ mediates poly I:C-induced onset of type 1 diabetes, RNase $\mathrm{L}^{+/+}$and RNase $\mathrm{L}^{-/-}$RIP-B7.1 mice received injections (i.p.) of $5 \mu \mathrm{g} / \mathrm{g}$ body weight poly I:C daily for 7 days, and then injections (i.p.) of insulin at a dose of $25 \mu \mathrm{g} /$ mouse on day 14 after poly I:C treatment. Diabetic progress in these mice was monitored every week and mice were considered diabetic after observation of two consecutive blood glucose values of at least $250 \mathrm{mg} / \mathrm{dl}$. As shown in Fig. 3C, the onset of diabetes was significantly delayed in the RNase $\mathrm{L}^{-/-}$RIP-B7.1 mice.

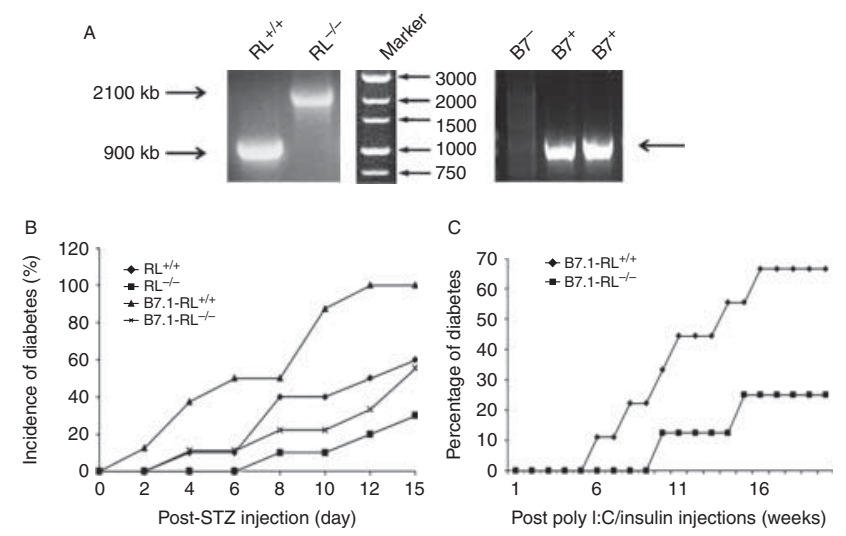

\section{Figure 3}

Effect of RNase L on STZ- and poly I:C-induced diabetes. (A) Genotyping of B7.1-RL ${ }^{-1-}$ mice. (B) Incidence of diabetes in RNase $\mathrm{L}(\mathrm{RL})^{+/+}$and

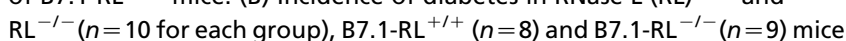
after injection of $40 \mathrm{mg} / \mathrm{kg}$ STZ for five consecutive days. (C) Incidence of diabetes in B7.1-RL ${ }^{+/+}(n=9)$ and B7.1-RL ${ }^{-1-}(n=8)$ mice after injection of $5 \mu \mathrm{g} / \mathrm{g}$ body weight poly I:C intraperitoneally daily for 7 days, and then injection of $25 \mu \mathrm{g} /$ mouse of insulin intraperitoneally on day 14 after poly I:C treatment. The glucose levels in the blood samples were measured using a blood sugar test kit (Pointe Scientific). Mice were considered diabetic after measurement of two consecutive blood glucose values of at least $250 \mathrm{mg} / \mathrm{dl}$. 


\section{RNase L facilitates infiltration of immune cells}

RNase $\mathrm{L}$ is highly expressed in the thymus, spleen, and all immune cells examined. As the infiltration of immune cells initiates the progress of this disease, we investigated whether the delay in the onset of type 1 diabetes was caused by slowdown of immune responses in the pancreases of RNase L-deficient mice. RNase $\mathrm{L}^{+/+}$and RNase $\mathrm{L}^{-/-}$RIP-B7.1 mice were treated with poly I:C for 40 days and then killed and the pancreatic tissues were embedded and sectioned at a thickness of $5 \mu \mathrm{m}$, followed by hematoxylin and eosin (H\&E) staining. Interestingly, the population of infiltrated immune cells was strikingly reduced in the islets of RNase $\mathrm{L}^{-/-}$mice, indicating that the involvement of RNase L in poly I:C-induced onset of diabetes may be through the regulation of the infiltration of immune cells (Fig. 4A). To determine the identity of these infiltrated immune cells, immunohistostaining for macrophages, $\mathrm{CD} 4^{+}$, and $\mathrm{CD} 8{ }^{+} \mathrm{T}$ cells was performed. Apparently, the majority of the infiltrated immune cells in the islets of the pancreas from RNase $\mathrm{L}^{+/+}$mice were CD8-positive $\mathrm{T}$ cells, although some CD4-positive $\mathrm{T}$ cells were found in islets from both types of mice (Fig. 4B). However, macrophages were undetectable in the islets from both types of mice using either CD11b or F4/80 as a biomarker (not shown). The finding indicates that CD8-positive $T$ cells may be the effector cells in the destruction of $\beta$-cells in the islets of the pancreas from RNase $\mathrm{L}^{+/+}$RIP-B7.1 mice after poly I:C treatment. As expected, the insulin levels in the islets of RNase $\mathrm{L}^{-1-}$ mice were significantly higher than those in RNase $\mathrm{L}^{+/+}$ mice before and after poly I:C treatment (Fig. 4C).

\section{RNase $L$ is associated with subclasses of immune cells in the spleen and T cell function in the blood}

RNase $\mathrm{L}^{-1-}$ mice display enlarged, hypercellular thymuses, indicating that RNase L may be involved in the development of thymocytes and $\mathrm{T}$ cell function. To determine whether RNase $\mathrm{L}$ affects $\mathrm{T}$ cell function, lymphocytes isolated from the blood of RNase $\mathrm{L}^{+/+}$and RNase $\mathrm{L}^{-1-}$ mice were subjected to analysis of their cytotoxic activity against retinal endothelial cells. As shown in Fig. $5 \mathrm{~A}$, lymphocytes from $\mathrm{RNase}^{-1-}$ mice exerted $46 \%$ lower cytotoxic activity than those from RNase $\mathrm{L}^{+/+}$mice. $\mathrm{CD} 4{ }^{+} \mathrm{CD} 25^{+}$regulatory T cells (Tregs) have emerged as a dominant peripheral mechanism of immune suppression of self-reactive $\mathrm{T}$ cells and a master switch factor controlling the balance between tolerance and immunity (Johnson et al. 2013). It has
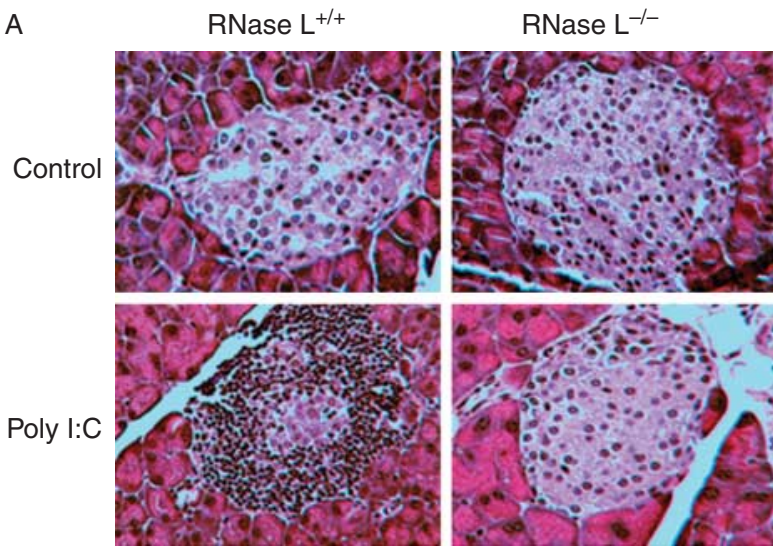

B

RNase $\mathrm{L}^{+/+}$
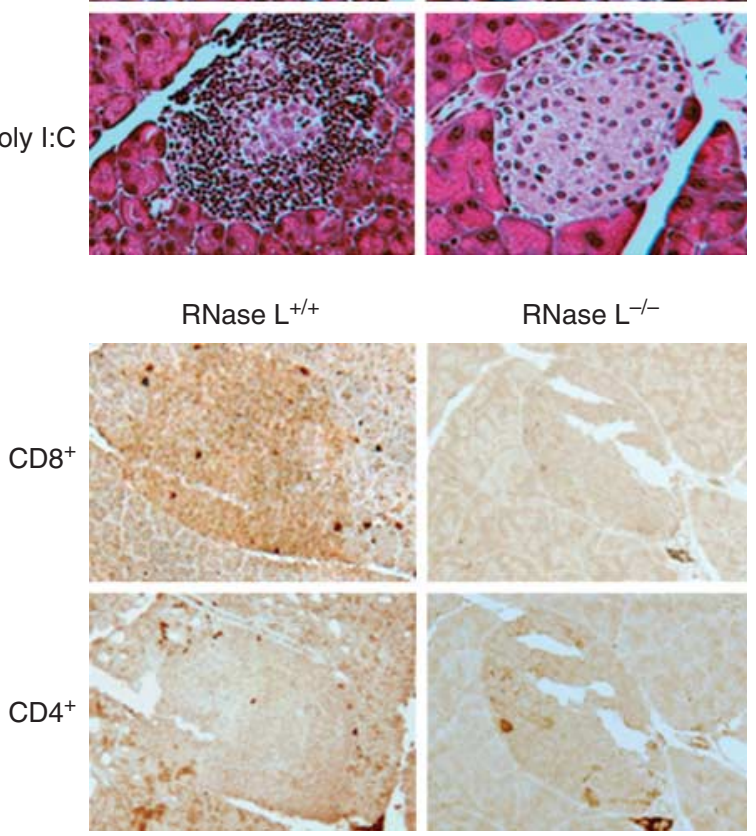

C

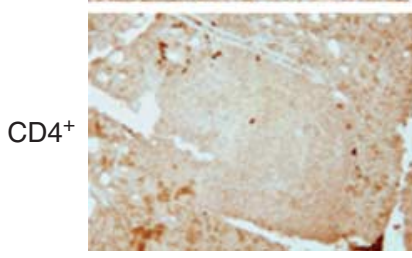

C $\quad$ RNase $\mathrm{L}^{+/+}$

RNase $\mathrm{L}^{-1-}$
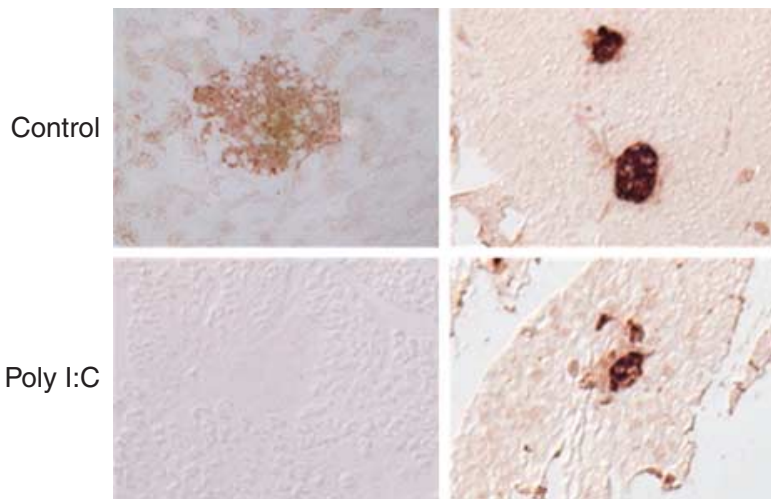

Figure 4

RNase-L-dependent infiltration of immune cells in the islets in response to poly I:C. (A) Hematoxylin and eosin-stained pancreatic islets from $\mathrm{B} 7.1-\mathrm{RL}^{+/+}$and B7.1-RL ${ }^{-1-}$ mice after treatment with or without poly I:C. (B) Immunohistological staining of $\mathrm{CD} 4^{+}$and $\mathrm{CD} 8^{+} \mathrm{T}$ cells in the islets from the two types of mice after poly I:C treatment. (C) Immunohistological staining of insulin in the islets from the two types of mice before and after poly I:C treatment. Magnification $\times 40$.

been demonstrated that $\mathrm{CD} 4^{+} \mathrm{CD} 25^{+}$Tregs, in particular $\mathrm{CD}^{+} \mathrm{CD}^{2} 5^{+} \mathrm{FoxP}^{+}$Tregs, are very important in controlling the development of diabetes in NOD mice (Manirarora et al. 2008, Kaminitz et al. 2014).

Published by Bioscientifica Ltd. 

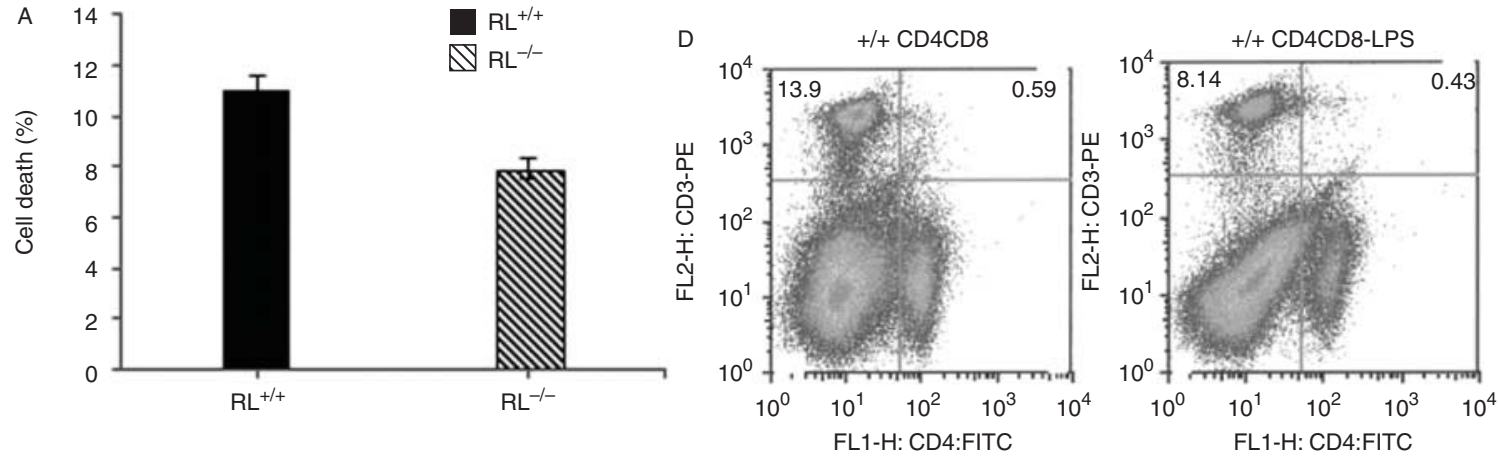

$B$
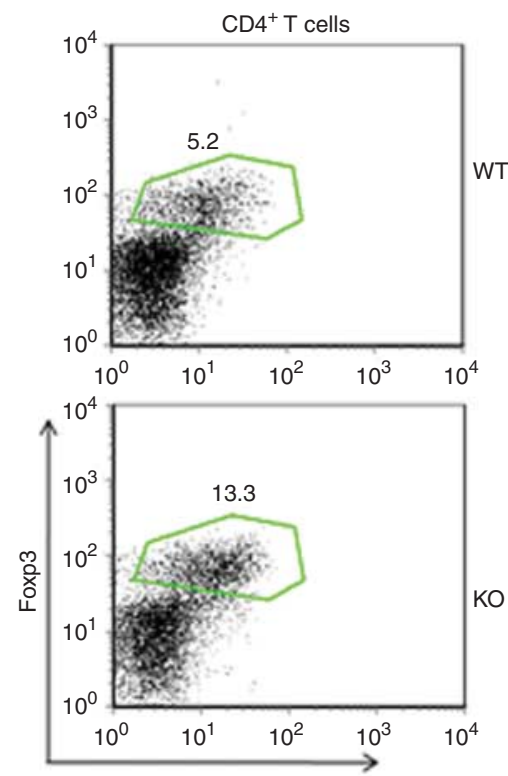

C

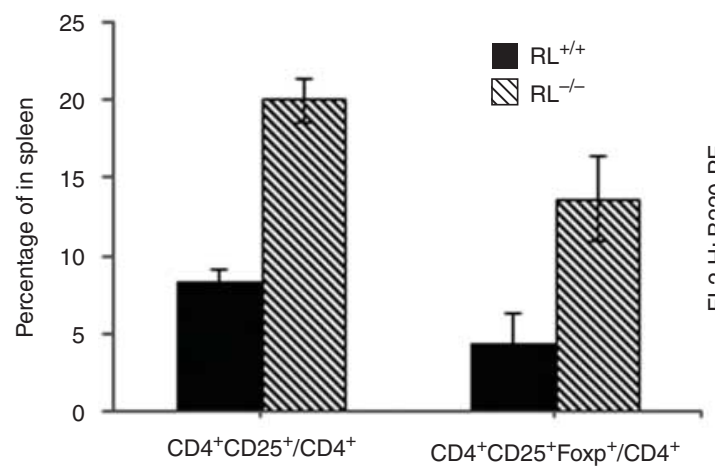

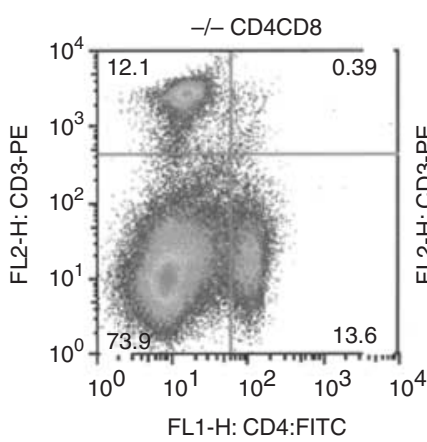
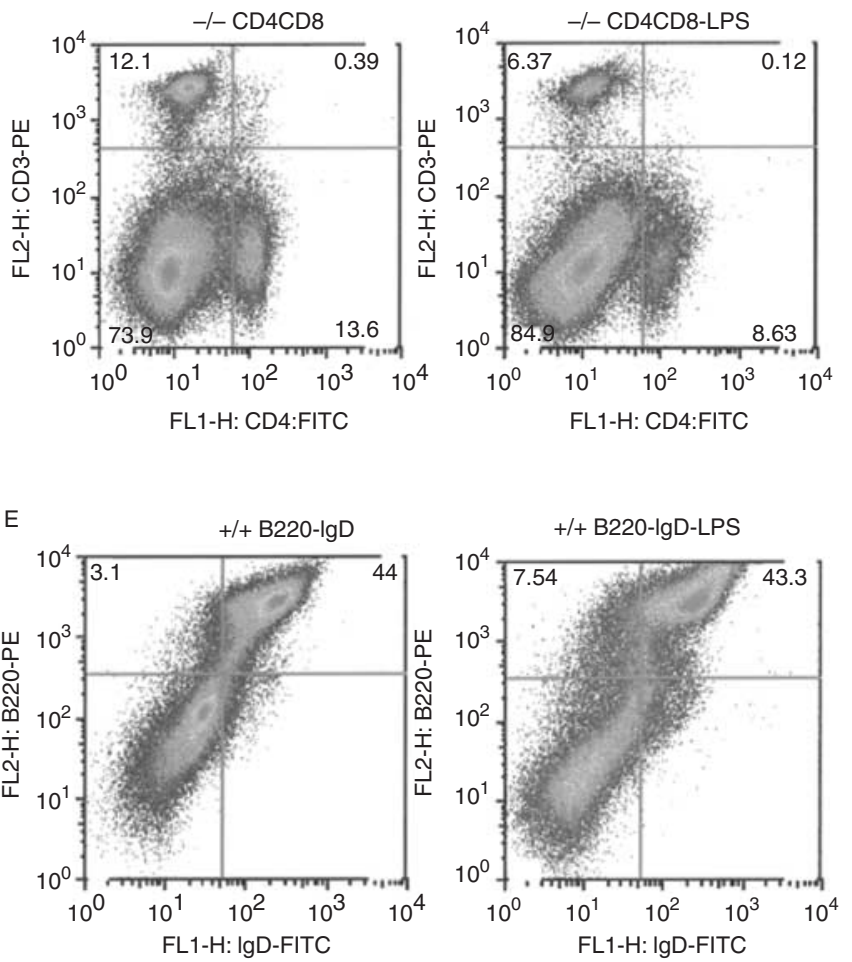

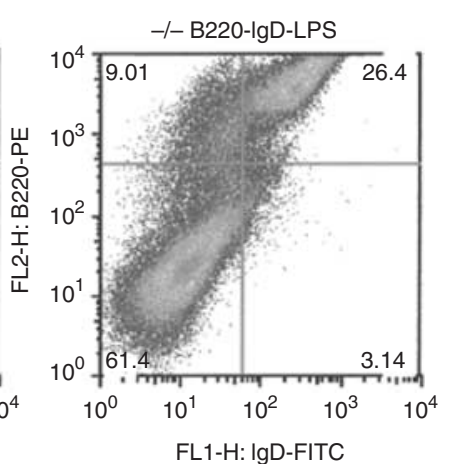

Figure 5

Effect of RNase $L$ on splenic immune cell subtypes and T cell function. (A) Lymphocytes isolated from RNase $\mathrm{L}^{+/+}$and RNase $\mathrm{L}^{-1-}$ mice ( $n=4 /$ group) were incubated with retinal endothelial cells at $1: 5$ at $37^{\circ} \mathrm{C}$ for $24 \mathrm{~h}$. Cell viability was measured by trypan blue exclusion. Samples were run in triplicate and the data are expressed as mean \pm S.D., $* * * P<0.048$. (B and C) Tregs in the spleens of RNase $\mathrm{L}^{+/+}$(WT) and RNase $\mathrm{L}^{-/-}$(KO) mice were analyzed for the expression of $\mathrm{CD} 4$ and $\mathrm{CD} 25$ by flow cytometric analysis. The percentages of
$\mathrm{CD} 4{ }^{+} \mathrm{CD} 25^{+}$Tregs and $\mathrm{CD} 4{ }^{+} \mathrm{CD} 25^{+}$Foxp3 Terg cells in total $\mathrm{CD} 4{ }^{+} \mathrm{T}$ cells are expressed as mean \pm s.D. $(n=4)$. ${ }^{*} P<0.05$; $* * P<0.025$. ( $D$ and $\left.E\right)$ Six-week-old male RNase $\mathrm{L}^{+/+}$and RNase $\mathrm{L}^{-/-}$mice (three mice per group) were treated with or without $25 \mu \mathrm{g}$ LPS for each mouse every other day for a week. The splenic cells were subjected to cell sorting after labeling with CD4, CD8, B220, and $\operatorname{lgD}$ alone or in combination. A full colour version of this figure is available via http://dx.doi.org/10.1530/JOE-14-0509. 
To determine the effect of RNase $\mathrm{L}$ on $\mathrm{CD} 4{ }^{+} \mathrm{CD} 25^{+}$ Tregs, we performed a flow cytometric assay to analyze the subtype of these cells in the spleen of RNase $\mathrm{L}^{+/+}$and RNase $\mathrm{L}^{-1-}$ mice. Interestingly, the percentage of $\mathrm{CD} 4{ }^{+} \mathrm{CD} 25^{+}$Tregs in $\mathrm{CD} 4{ }^{+} \mathrm{T}$ cells in the spleens of RNase $\mathrm{L}^{-1-}$ mice was significantly higher than that in those of RNase $\mathrm{L}^{+/+}$mice. In particular the percentage of $\mathrm{CD}^{+}{ }^{+} \mathrm{CD} 25^{+}$foxP $3{ }^{+}$Tregs in $\mathrm{CD} 4{ }^{+} \mathrm{T}$ cells was $13.3 \%$ in the spleens of RNase $\mathrm{L}^{-/}$mice when compared with $5.2 \%$ in the spleens of RNase $\mathrm{L}^{+/+}$mice (Fig. 5B and C). The population of other cell subclasses was also differentially represented in the spleens of RNase $\mathrm{L}^{+/+}$and RNase $\mathrm{L}^{-/-}$mice, especially under stimulation with LPS as shown in Fig. $5 \mathrm{D}$ and $\mathrm{E}$. The population of $\mathrm{CD} 4^{+} \mathrm{CD} 8^{+} \mathrm{T}$ cells in the spleens of RNase $\mathrm{L}^{-/}$mice was $37 \%$ less than that in the spleens of RNase $\mathrm{L}^{+/+}$mice, whereas the population of the double-labeled $\mathrm{T}$ cells was $72 \%$ less in the spleens of RNase $\mathrm{L}^{-/-}$mice when compared with that in the spleens of RNase $\mathrm{L}^{+/+}$mice after treatment with LPS. Similar to $\mathrm{CD} 4^{+} \mathrm{CD}^{+} \mathrm{T}$ cells, the population of $\mathrm{B}_{220^{+}} \mathrm{IgD}^{+} \mathrm{B}$ cells in the spleens of RNase $\mathrm{L}^{-/-}$mice was $39 \%$ less than that in the spleens of RNase $\mathrm{L}^{+/+}$mice after LPS stimulation, although the population of $\mathrm{B}_{22} \mathrm{O}^{+} \mathrm{IgD}^{+} \mathrm{B}$ cells in the spleens of intact RNase $\mathrm{L}^{-/-}$ mice was slightly higher than that in the spleens of RNase $\mathrm{L}^{+/+}$mice under the same conditions. Taken together, the results implicate RNase $\mathrm{L}$ in immune system activities through mediating the context-specific modulation of immune cell subclasses in the spleen.

\section{The expression of proinflammatory cytokines in the pancreatic tissues}

In addition to IFN $\alpha$, several proinflammatory genes such as $T N F \alpha, I L 1 \beta$, and $I F N \gamma$ are believed to contribute to the development of type 1 diabetes (Solomon \& Sarvetnick 2004, Anderson \& Bluestone 2005). To determine whether deficiency of RNase $\mathrm{L}$ affects the expression of TNF $\alpha$, IL1 $\beta$, IL6, and IFN $\gamma$, RNase $\mathrm{L}^{+/+}$and RNase $\mathrm{L}^{-/-}$RIP-B7.1 mice were treated with poly I:C at a concentration of $5 \mu \mathrm{g} / \mathrm{g}$ body weight every other day for a week and the level of these gene products in the pancreatic extracts was determined by ELISA. As shown in Fig. 6, RNase L deficiency reduced IFN $\gamma$ and $\mathrm{TNF} \alpha$ production by 37.5 and $48.5 \%$, respectively, in the pancreas after treatment with poly I:C. However, the expression of IL1 $\beta$ and IL6 was found to be slightly higher in the pancreases from RNase $\mathrm{L}^{+/+}$mice when compared with the pancreases from RNase- $\mathrm{L}^{-/-}$mice.

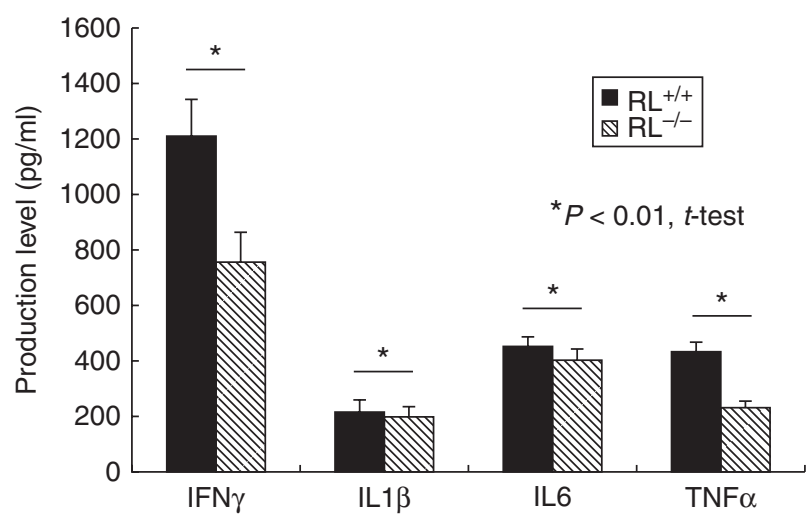

Figure 6

$R N a s e \mathrm{~L}$ regulates the expression of proinflammatory genes. RNase L-deficient and WT RIP-B7.1 mice were treated with poly I:C at a concentration of $5 \mu \mathrm{g} / \mathrm{g}$ body weight every other day for a week and the level of these factors in the pancreatic extracts was determined by ELISA using an ELISA kit for each of the analyzers. Experiments were carried out two times in triplicates. Data are expressed as mean \pm s.D., $P<0.01$.

\section{Discussion}

B7.1 and B7.2 are homologous costimulatory ligands expressed on the surface of antigen-presenting cells (APCs). Binding of these molecules to the T cell costimulatory receptors, CD28 and CTLA-4, is essential for the activation and regulation of $\mathrm{T}$ cell immunity (Greenwald et al. 2005). Although expression of the B7.1 costimulator alone is not sufficient to induce diabetes in mice, $\beta$-cells expressing the molecule are more vulnerable to harmful environmental factors such as viral infection, resulting in the destruction of $\beta$-cells and leading to disease (Wong et al. 1995). As a mimic of viral infection, poly I:C treatment alone can induce insulitis, but cannot lead to diabetes in C57BL/6 mice. However, it can effectively induce diabetes in C57BL/ 6 mice expressing B7.1 on $\beta$-cells in the islets under the control of a RIP (Devendra et al. 2005). In this study, we present evidence indicating that RNase $\mathrm{L}^{-1-}$ RIP-B7.1 mice display a significant delay of type 1 diabetes onset induced by poly $\mathrm{I}: \mathrm{C}$, indicating that RNase $\mathrm{L}$ is associated with the pathogenesis of this disease.

The role of RNase $\mathrm{L}$ in mediating IFN-induced actions against viral infection and cell proliferation has been well established. A line of evidence has shown that IFN $\alpha$ plays a vital role in initiating autoimmune responses and the molecular mechanism is a continuing subject of investigation. Studies have revealed that the onset of type 1 diabetes in animal models induced by STZ and poly I:C is IFN $\alpha$-dependent (Huang et al. 1994, Devendra et al. 2005). In humans, the development of type 1 diabetes has been widely documented during IFN $\alpha$ therapy for viral infections

Published by Bioscientifica Ltd. 
such as hepatitis B and C (di Cesare et al. 1996, Kose et al. 2012). How IFN $\alpha$ promotes the onset of type 1 diabetes remains to be further elucidated. RNase $\mathrm{L}$ is one of the key enzymes in the 2-5A system of IFN $\alpha$ function. 2-5A activation of RNase $\mathrm{L}$ results in apoptosis in cells. It is believed that apoptosis is one of the key factors in triggering autoimmune responses in islets (Kawazoe et al. 2012). Thus, our results indicate that poly I:C treatment may induce an increase in IFN $\alpha$ production in islets and subsequently activate the $2-5 \mathrm{~A}$ system. Activation of the 2-5A system, in turn, leads to $\beta$-cell apoptosis, which further promotes the autoimmune responses resulting in destruction of $\beta$-cells and diabetes onset. Deficiency of RNase L in mice delays the onset of type 1 diabetes. Actually, this hypothesis is supported by a previous study in which poly I:C induces cell apoptosis in pancreatic islets, resulting in the release of islet autoantigens, triggering the autoimmune responses. By contrast, none of the bacterial products such as LPS and CpG are able to induce diabetes in these mice because they cannot induce islet cells to undergo overt apoptosis (Maniati et al. 2008).

RNase L may be involved directly in the action of immune cells to affect the development of type 1 diabetes. Although $\mathrm{T}$ lymphocytes are primarily the effectors, results from previous studies have indicated that B cells may play a vital role in the pathogenesis of autoimmune diseases. In NOD mice, the contribution of B cells was clearly demonstrated by the remarkable reduction in the incidence of insulitis and diabetes after B cell depletion using anti-IgM antibodies at birth or in NOD mice genetically deficient in B cells (Silveira \& Grey 2006, Mariño et al. 2011). Using the same animal model, it has been demonstrated that B cells function as islet antigen-presenting cells for autoreactive $\mathrm{T}$ cells and produce antibodies that are directly pathogenic. In clinical trials, patients with type 1 diabetes treated with rituximab, a chimeric MAB against the protein $\mathrm{CD} 20$ that is primarily found on the surface of B cells, decreased C-peptide and reduced insulin requirements, indicating an essential role of $\mathrm{B}$ cells in the development of this disease (Pescovitz et al. 2009). Interestingly, the

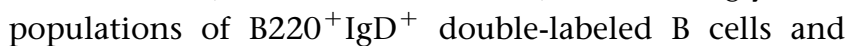
$\mathrm{CD}^{+} / \mathrm{CD}^{+}$double-labeled $\mathrm{T}$ cells were $39 \%$ and $72 \%$ down after LPS treatment (Fig. 2A) or $46 \%$ and $45 \%$ down after poly I:C treatment (data not shown) in the spleens of RNase $\mathrm{L}^{-/-}$mice, indicating that delayed onset of type 1 diabetes may be due to attenuated immune responses as a result of decreases in the population of certain immune cells, such as B cells, induced by LPS or poly I:C. The effect of RNase L on immunity is a focus of our current investigations.

The production of proinflammatory genes in the islets plays a critical role in the pathogenesis of type 1 diabetes.
It has been demonstrated that disruption of IFN $\gamma$ function using either IFN $\gamma$-specific Abs or soluble IFN $\gamma$ receptors (IFN $\gamma \mathrm{R}$ ) significantly reduces the incidence of spontaneous diabetes in NOD mice, indicating an important role of IFN $\gamma$ in the development of this disease (Campbell et al. 1991, Nicoletti et al. 1996). Complete protection from diabetes was observed when Tnfr1, but not Tnfr2 was knocked out in NOD mice although the direct effect of TNFR1 on $\beta$-cell death in vivo has not been defined clearly (Kägi et al. 1999). It has been reported that RNase L mediates the expression of certain genes through regulating RNA turnover (Bisbal et al. 2000, Chandrasekaran et al. 2004). Our results indicate that RNase L specifically regulating the expression of proinflammatory genes in the pancreas may contribute to the onset of type 1 diabetes induced by poly I:C. Interestingly, RNase L seemed not to influence the growth rate of mice fed a high-fat diet, but the level of blood glucose in RNase $\mathrm{L}^{-1-}$ mice was significantly higher although the insulin level was markedly increased, indicating that insulin sensitivity in RNase $\mathrm{L}^{-1-}$ cells may be impaired. Indeed, we have observed that phosphorylation of Akt, a key component of the insulin signaling pathway, in RNase $\mathrm{L}^{-/-}$MEFs and primary hepatocytes stimulated by insulin was significantly reduced when compared with that in the same type of RNase $\mathrm{L}^{+/+}$cells (L Zhang and A Zhou unpublished observations). Thus, this study highlights the potential benefits of targeting RNase L in treatment of type 1 diabetes.

\section{Declaration of interest}

The authors declare that there is no conflict of interest that could be perceived as prejudicing the impartiality of the research reported.

\section{Funding}

This work was supported by Marousch Award, the Diabetes Association of Greater Cleveland to $A \mathrm{Z}$ and partially by grants from the National Institutes of Health (R15DK084460-01A2) to A Z and (AI089518) to K M.

\section{Acknowledgements}

The authors thank Dr Bret A Hassel (University of Maryland School of Medicine) for helpful comments on the manuscript.

\section{References}

Anderson MS \& Bluestone JA 2005 The NOD mouse: a model of immune dysregulation. Annual Review of Immunology 23 447-485. (doi:10.1146/ annurev.immunol.23.021704.115643)

Bergholdt R, Heding P, Nielsen K, Nolsøe R, Sparre T, Størling J, Nerup J, Pociot F \& Mandrup-Poulsen T 2004 Type 1 database mellitus: an

Published by Bioscientifica Ltd. 
inflammatory disease of the islet. Advances in Experimental Medicine and Biology 552 129-153.

Bisbal C, Silhol M, Laubenthal H, Kaluza T, Carnac G, Milligan L, Le Roy F \& Salehzada T 2000 The $2^{\prime}-5^{\prime}$ oligoadenylate/RNase L/RNase L inhibitor pathway regulates both MyoD mRNA stability and muscle cell differentiation. Molecular and Cellular Biology 20 4959-4969. (doi:10. 1128/MCB.20.14.4959-4969.2000)

Bonnevie-Nielsen V, Martensen PM, Justesen J, Kyvik KO, Kristensen B, Levin K, Beck-Nielsen H, Worsaa A \& Dyrberg T 2000 The antiviral 2', 5'oligoadenylate synthetase is persistently activated in type 1 diabetes. Clinical Immunology 96 11-18. (doi:10.1006/clim.2000.4874)

Campbell IL, Kay TW, Oxbrow L \& Harrison LC 1991 Essential role for interferon- $\gamma$ and interleukin- 6 in autoimmune insulin-dependent diabetes in NOD/Wehi mice. Journal of Clinical Investigation $\mathbf{8 7}$ 739-742. (doi:10.1172/JCI115055)

di Cesare E, Previti M, Russo F, Brancatelli S, Ingemi MC, Scoglio R, Mazzù N, Cucinotta D \& Raimondo G 1996 Interferon- $\alpha$ therapy may induce insulin autoantibody development in patients with chronic viral hepatitis. Digestive Diseases and Sciences 41 1672-1677. (doi:10.1007/BF02087923)

Chandrasekaran K, Mehrabian Z, Li X-L \& Hassel B 2004 RNase-L regulates the stability of mitochondrial DNA-encoded mRNAs in mouse embryo fibroblasts. Biochemical and Biophysical Research Communications 325 18-23. (doi:10.1016/j.bbrc.2004.10.016)

Chehadeh W, Weill J, Vantyghem MC, Alm G, Lefèbvre J, Wattré P \& Hober D 2000 Increased level of interferon- $\alpha$ in blood of patients with insulin-dependent diabetes mellitus: relationship with coxsackievirus B infection. Journal of Infectious Diseases 181 1929-1939. (doi:10.1086/ 315516)

Coppieters KT \& von Herrath MG 2011 Viruses and cytotoxic T lymphocytes in type 1 diabetes. Clinical Reviews in Allergy \& Immunology 41 169-178. (doi:10.1007/s12016-010-8220-4)

Coppieters KT, Dotta F, Amirian N, Campbell PD, Kay TWH, Atkinson MA, Roep BO \& von Herrath MG 2012 Demonstration of islet-autoreactive CD8 T cells in insulitic lesions from recent onset and long-term type 1 diabetes patients. Journal of Experimental Medicine 209 51-60. (doi:10.1084/jem.20111187)

Devendra D, Jasinski J, Melanitou E, Nakayama M, Li M, Hensley B, Paronen J, Moriyama H, Miao D, Eisenbarth GS et al. 2005 Interferon- $\alpha$ as a mediator of polyinosinic:polycytidylic acid-induced type 1 diabetes. Diabetes 54 2549-2556. (doi:10.2337/diabetes.54.9.2549)

Fabre O, Salehzada T, Lambert K, Boo Seok Y, Zhou A, Mercier J \& Bisbal C 2012 RNase L controls terminal adipocyte differentiation, lipids storage and insulin sensitivity via CHOP10 mRNA regulation. Cell Death and Differentiation 19 1470-1481. (doi:10.1038/cdd.2012.23)

Greenwald RJ, Freeman GJ \& Sharpe AH 2005 The B7 family revisited. Annual Review of Immunology 23 515-548. (doi:10.1146/annurev. immunol.23.021704.115611)

Hassel BA, Zhou A, Sotomayor C, Maran A \& Silverman RH 1993 A dominant negative mutant of 2-5A-dependent RNase suppresses antiproliferative and antiviral effects of interferon. EMBO Journal 12 3297-3304.

Huang X, Hultgren B, Dybdal N \& Stewart TA 1994 Islet expression of interferon- $\alpha$ precedes diabetes in both the BB rat and streptozotocin-treated mice. Immunity 1 469-478. (doi:10.1016/ 1074-7613(94)90089-2)

Johnson MC, Garland AL, Nicolson SC, Li C, Samulski RJ, Wang B \& Tisch R $2013 \beta$-cell-specific IL-2 therapy increases islet Foxp $3^{+}$Treg and suppresses type 1 diabetes in NOD mice. Diabetes 62 3775-3784. (doi:10.2337/db13-0669)

Kägi D, Ho A, Odermatt B, Zakarian A, Ohashi PS \& Mak TW 1999 TNF receptor 1-dependent $\beta$ cell toxicity as an effector pathway in autoimmune diabetes. Journal of Immunology 162 4598-4605.

Kaminitz A, Mizrahi K, Ash S, Ben-Nun A \& Askenasy N 2014 Stable activity of diabetogenic cells with age in NOD mice: dynamics of reconstitution and adoptive diabetes transfer in immunocompromised mice. Immunology 142 465-473. (doi:10.1111/imm.12277)

Kawazoe T, Araki M, Lin Y, Ogawa M, Okamoto T, Yamamura T, Wakakura M \& Murata M 2012 New-onset type 1 diabetes mellitus and anti-aquaporin- 4 antibody positive optic neuritis associated with type 1 interferon therapy for chronic hepatitis C. Internal Medicine $\mathbf{5 1}$ 2625-2629. (doi:10.2169/internalmedicine.51.7771)

Kose S, Gozaydin A, Akkoclu G \& Ece G 2012 Chronic hepatitis B with type I diabetes mellitus and autoimmune thyroiditis development during interferon $\alpha$ therapy. Journal of Infection in Developing Countries 6 364-368. (doi:10.3855/jidc.1749)

Leitner WW, Hwang LN, deVeer MJ, Zhou A, Silverman RH, Williams BR, Dubensky TW, Ying H \& Restifo NP 2003 Alphavirus-based DNA vaccine breaks immunological tolerance by activating innate antiviral pathways. Nature Medicine 9 33-39. (doi:10.1038/nm813)

Li Q, Xu B, Michie SA, Rubins KH, Schreriber RD \& McDevitt HO 2008 Interferon- $\alpha$ initiates type 1 diabetes in nonobese diabetic mice. PNAS 105 12439-12444. (doi:10.1073/pnas.0806439105)

Mandrup-Poulsen T 2003 Apoptotic signal transduction pathways in diabetes. Biochemical Pharmacology 66 1433-1440. (doi:10.1016/S00062952(03)00494-5)

Maniati E, Potter P, Rogers NJ \& Morley BJ 2008 Control of apoptosis in autoimmunity. Journal of Pathology 214 190-198. (doi:10.1002/path.2270)

Manirarora JN, Kosiewicz MM, Parnell SA \& Alard P 2008 APC activation restores functional $\mathrm{CD} 4{ }^{+} \mathrm{CD} 25^{+}$regulatory T cells in NOD mice that can prevent diabetes development. PLoS ONE 3 e3739. (doi:10.1371/ journal.pone.0003739)

Mariño E, Silveira PA, Stolp J \& Grey ST 2011 B cell-directed therapies in type 1 diabetes. Trends in Immunology 32 287-294. (doi:10.1016/j.it. 2011.03.006)

Mathis D, Vence L \& Benoist C $2001 \beta$-Cell death during progression to diabetes. Nature 414 792-798. (doi:10.1038/414792a)

Nicoletti F, Zaccone P, Di Marco R, Di Mauro M, Magro G, Grasso S, Mughini L, Meroni P \& Garotta G 1996 The effects of a nonimmunogenic form of murine soluble interferon- $\gamma$ receptor on the development of autoimmune diabetes in the NOD mouse. Endocrinology $\mathbf{1 3 7}$ $5567-5575$

Nolan-Sorden NL, Lesiak K, Bayard B, Torrence PF \& Silverman RH 1990 Photochemical crosslinking in oligonucleotide-protein complexes between a bromine-substituted 2-5 A analog and 2-5A-dependent RNase by ultraviolet lamp or laser. Analytical Biochemistry 184 298-304. (doi:10.1016/0003-2697(90)90684-2)

Pescovitz MD, Greenbaum CJ, Krause-Steinrauf H, Becker DJ, Gitelman SE, Goland R, Gottlieb PA, Marks JB, McGee PF, Moran AM et al. 2009 Rituximab, B-lymphocyte depletion, and preservation of $\beta$-cell function. New England Journal of Medicine 361 2143-2152. (doi:10.1056/ NEJMoa0904452)

Selmi C, Lleo A, Zuin M, Podda M, Rossaro L \& Gershwin ME 2006 Interferon $\alpha$ and its contribution to autoimmunity. Current Opinion in Investigational Drugs 7 451-456.

Silveira PA \& Grey ST 2006 B cells in the spotlight: innocent bystanders or major players in the pathogenesis of type 1 diabetes. Trends in Endocrinology and Metabolism 17 128-135. (doi:10.1016/j.tem.2006.03.006)

Silverman RH 1996 2-5A dependent RNase L: a regulated endoribonuclease in the IFN system. In Ribonucleases: Structure and Function, pp 517-547. Eds G D'alessio \& JF Riordan. New York: Academic Press, Inc.

Silverman RH, Zhou A, Auerbach MB, Kish D, Gorbachev A \& Fairchild RL 2002 Skin allograft rejection is suppressed in mice lacking the antiviral enzyme, 2',5'-oligoadenylate-dependent RNase L. Viral Immunology $\mathbf{1 5}$ 77-83. (doi:10.1089/088282402317340242)

Solomon M \& Sarvetnick N 2004 The pathogenesis of diabetes in the NOD mouse. Advances in Immunology 84 239-264. (doi:10.1016/S00652776(04)84007-0)

Stewart TA, Hultgren B, Huang X, Pitts-Meek S, Hully J \& MacLachlan NJ 1993 Induction of type I diabetes by interferon- $\alpha$ in transgenic mice. Science 260 1942-1946. (doi:10.1126/science.8100367) 
Wong S, Guerder S, Visintin I, Reich EP, Swenson KE, Flavell RA \& Janeway CA Jr 1995 Expression of the co-stimulator molecule B7-1 in pancreatic $\beta$-cells accelerates diabetes in the NOD mouse. Diabetes 44 326-329. (doi:10.2337/diab.44.3.326)

Yi X, Zeng C, Liu H, Chen X, Zhang P, Yun BS, Jin G \& Zhou A 2013 Lack of RNase L attenuates macrophage functions. PLOS ONE 8 e81269. (doi:10.1371/journal.pone.0081269)

Yoon JW \& Jun HS 2001 Cellular and molecular pathogenic mechanisms of insulin-dependent diabetes mellitus. Annals of the New York Academy of Sciences 928 200-211. (doi:10.1111/j.1749-6632.2001. tb05650.x)
Zhou A, Hassel BA \& Silverman RH 1993 Expression cloning of 2-5Adependent RNAase: a uniquely regulated mediator of interferon action. Cell 72 753-765. (doi:10.1016/0092-8674(93)90403-D)

Zhou A, Paranjape J, Brown TL, Nie H, Naik S, Dong B, Chang A, Trapp B, Fairchild R, Colmenares C et al. 1997 Interferon action and apoptosis are defective in mice devoid of $2^{\prime}, 5^{\prime}$-oligoadenylate-dependent RNase $\mathrm{L}$. EMBO Journal 16 6355-6363. (doi:10.1093/emboj/16.21.6355)

Zhou A, Paranjape JM, Hassel BA, Nie H, Shah S, Galinski B \& Silverman RH 1998 Impact of RNase L overexpression on viral and cellular growth and death. Journal of Interferon \& Cytokine Research 18 953-961. (doi:10.1089/jir.1998.18.953)

Received in final form 30 September 2014

Accepted 6 October 2014

Accepted Preprint published online 6 October 2014
Published by Bioscientifica Ltd. 